\title{
The Behavior of Watching Television Media and the Effectivenes of Online Commercial Advertisement Messages in Young People
}

\author{
Dian Marhaeni Kurdaningsih ${ }^{1}$, Genta Maghvira ${ }^{2}$ \\ Communication Science, Universitas Islam Sultan Agung, Indonesia ${ }^{1,2}$ \\ \{marhaeni@unissula.ac.id ${ }^{1}$, genta@unissula.ac.id²
}

\begin{abstract}
Commercial messages through advertisements on television media in this online media era continue showing its existence. Television advertisements are appearing and do not diminish gradually significant. Commercial messages are even more creative with smart ideas. The audience seems fascinated by the appearance of creative advertising works. This study aims to determine the viewing behavior of young people in consuming media television especially commercial messages through advertisements and know the effectiveness of commercial messages advertising on television media. This research used qualitative methods and an interpretive paradigm. Data analysis was performed interactively from Miles and Huberman and including Islamic values into one of his perspectives. The research results are showed accurate data about the behavior of television viewers among young people in watching commercial advertising messages in television. So that it can shows the effectiveness of television advertising commercial messages.
\end{abstract}

Keywords: Television advertising, Young Audience, Interpretive, Watching Behavior, Online Media

\section{Introduction}

Recently television advertisements are still many adorn the television program in Indonesia. The total spending on television, radio and printed media advertising in 2019 was 168 trillion. Television is still dominating with $85 \%$ of the portion on advertising spending, it reach more than 143 trillion IDR, it increases 14 percent compared to the previous year, 2018. Meanwhile, printed media advertising spending reached more than 22 trillion IDR and the total radio advertising spending reached 1.7 trillion IDR. Throughout 2019, the online services category was the largest contributor to advertising spending with a total advertising spending is 10.3 trillion and it increase $2 \%$. (https://www.nielsen.com/id/id/pressreleases $/ 2020 /$ belanjaiklan-2019-ditutup-dengan-tren-positif/)

During 2019, the online services category was the largest contributor in advertising spending with 10.3 trillion IDR as total advertising expenditure, it increase 2 percent. Television advertisements was dominated by young endorser in penetrating the market. 


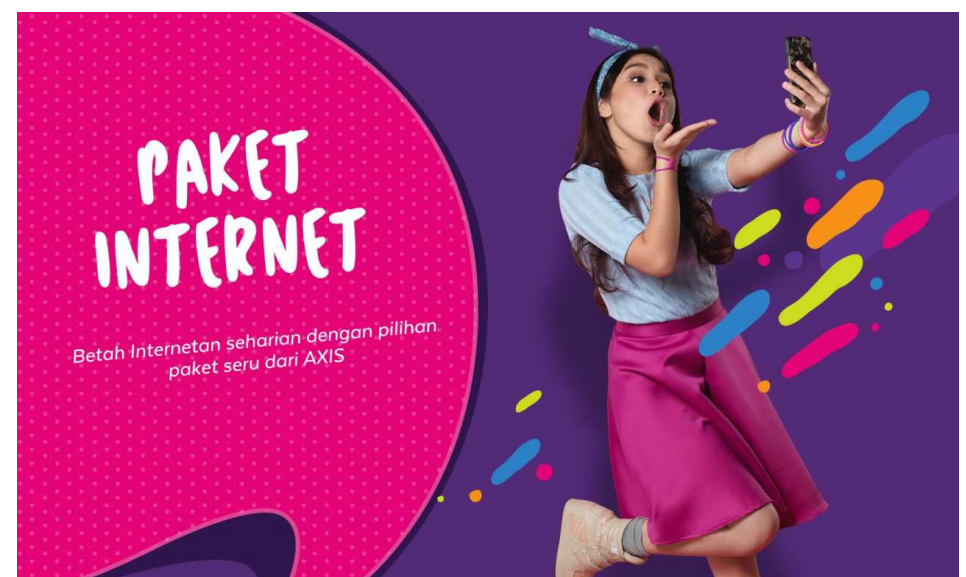

(Source: https://gadgetren.com/2020/01/25/daftar-paket-axis-di-tahun-2020-96566/)

Fig. 1. Example of advertisement provider with a young endorser

Of course it is not without reason to use young endorser, one of which is to hook the market and also to strengthen the character of the product. Based on the latest report of $W e$ Are Social, in 2020 it was mentioned that there are 175,4 million internet user in Indonesia. Compared to the previous year, there was an increase of $17 \%$ or 25 million internet users in Indonesia. Based on the total Indonesian Population of 272.1 million, it means that $64 \%$ or a half of Indonesian population has experienced to cyberspace. The percentage of internet users aged 16 to 64 who owned a device each, they are mobile phone (96\%), smartphone (94\%), non-smartphone mobile phone (21\%), laptop or desktop computer $966 \&)$, tables $(23 \%)$, game consoles $(16 \%)$ and virtual reality device (5.1\%).(https://inet.detik.com/cyberlife/d4907674/riset-ada-1752-juta-pengguna-internet-diindonesia, 1 Juni 2020)

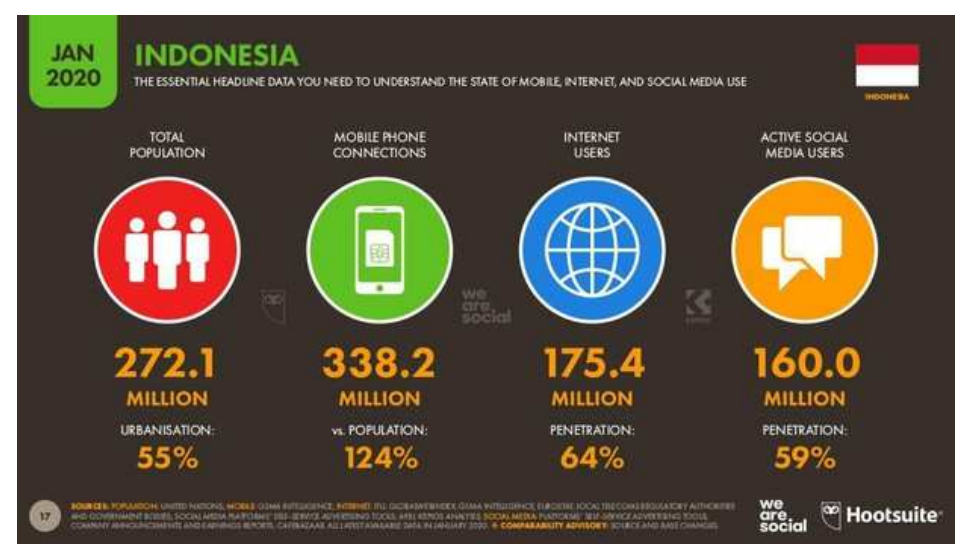

Fig. 2. The Percentage of Internet Users

In this report, it is also known that currently Indonesians who own cell phones are 338.2 million. Likewise, this data is no longer interesting, there are 160 million social media active users. This users is dominated by young people who are actively using internet and consuming online media messages. In the millennial era, these young audiences allegedly migrated from 
watching television to online media consumption. The increase in the use of online media continues to grow significantly, especially dominated by young people.

The high advertising spending in television media raises a question whether the television media is still effective as a media for advertising. When young people began to leave him and how the actual behavior of the young viewers like. The study is about to revel in detail with interpretive qualitative analysis how viewing behavior of young people in the millennial era.

It is seen from the point of view of commercial messages through television advertisement, the viewability level decrease day by day. In 2019, the data advertising research from entire duration of advertising impression were only able to reach $29 \%$ viewability of the audiences. The more declining of viewability level the more questioning on the effectiveness of television advertising. (Media Trials press realeases, 10 December 2019)

The previous study had been done by Engkus Kusmarno. He examined phenomenology research tradition in qualitative communication research that result in the development of research formats on the phenomenological tradition. The study on Television viewing behavior has also been carried out by Azza Abdel Azim Mohamed Ahmed entitled "A new era of television viewing behavior, watching party and its psychological impact. The study lead to the conclusion that there some factors, namely age, economy and education, brings impacts on this party-watching behavior. Azza observed viewing behavior party or watch in group manner and use streaming media in watching television. The researcher are now currently making observation on watching behavior at young people individually and use non-streaming television media.

The research methodology used is qualitative with including the Islamic values in each item of the analysis. If Engkus Kuswono focuses more on the theory and the format of phenomenological methodology in his research, so this study uses phenomenology as the analysis reinforcement in practical research. The analysis of Islamic values will provide its own characteristics that are different from the previous analysis. The novelty of the research in this study was showing the novelty of paradigm review namely using qualitative method and interpretive paradigm, also communication phenomenology analysis or communicology, effectiveness analysis by seeing the viewability and including Islamic values in each item.

\section{Theoretical Framework}

\section{Interpretive Paradigm}

This study is based on interpretive paradigm. Interpretive paradigm is at the opposite of positivistic. The overarching interpretive phenomenology paradigm explains that in life, social and human events are common sense. Thinking that the initial steps of research starts from meaning or meaning given the individual to his experiences and everyday life. Interpretive research is inductive, meaning that it starts from the specific to the general, from concrete to abstract. It is also ideographical, it is not nomothetic, meaning that reality can be expressed from symbols through descriptive forms. In this paradigm, knowledge cannot only be obtained through the senses, but understanding by involving the meaning and interpretation of the researcher is also more important. This paradigm states that science is not free of value because the free condition of the value is impossible to achieve. The data can be presented in different ways by different party who may have different interest. (Sarantakos, 1993)

Interpretive qualitative research bases the assumption that relationships do not separate between the researcher and the object of the study. Values and knowledge held by the 
researcher and informants both influence the research results. The truth is negotiable between two sides in the research. Through the dialogue, meaning are exchanged between the researcher and informants in order to obtain a detail, different, unique and comprehensive research result symptoms in society. Interpretive research places reality as a result of social construction, and it is liquid.

Negotiating the discovery of meaning in interpretive research involves all aspects of life that grow in the society, like social, cultural and community relation aspect. The result of interpretive research is specific which implies that the results of this study are not able to explain similar research in different setting of place. Likewise, when it is explaining the same phenomenon in different cultural systems and eras. Truth is relative, temporary, and changeable at any time following the context of time and place preceding it. (Sarantakos: 1993)

If the researcher tries to describe a phenomenon from a community according to their own view, the best tradition is using phenomenology. The tradition of phenomenological study as described by Cresswell that whereas a biography reports the life of a single individual, a phenomenological study describes the meaning of the live experiences for several individuals about a concept or the phenomenon (Creswell in Engkus:2007:164). Thus, a study with a phenomenological approach seeks to explain meaning the life experience of a number of people about a concept or symptom, including the concept of their own view of life (Engkus:2007:164).

Phenomenology assumes that researchers know the meaning of something from people who is being researched by them. Phenomenological inquiry begins in silence. Silence constitutes action to capture the understanding of something being researched. They are trying to get in into the conceptual world on the subjects it researches in such a way that they are understand what and how an understanding developed by them around the event in daily life (Moleong: 1999: 9).

The phenomenological approach includes into a subjective or interpretive approach as one of the point of view of human behavior, namely the objective and subjective approach. An objective or behavioristic and structural approach assumes that humans are passive, while the subjective approach views humans as active (phenomenological or interpretive)

LittleJohn describe the phenomenological tradition as the assumption that people are actively interpret experiences and try to understand the world with the personal experience (2017). The three basic principle of phenomenology are: first, knowledge found directly in conscious experience, we will know the world when we are related to him. Second, the meaning of things consist of the power of things in one's life or how the relation between you and things, and it determines what they mean to you. The third assumption is that language is a vehicle of meaning. We understand the world through the language used to define and express that world. Thus what Stanley Deetz said as quoted by Littlejohn.

Meanwhile, Craig stated that phenomenology sees more on individuals as a key component in the communication process. Phenomenology is the way humans understand the world through direct experience. 40 Much of the phenomenological tradition is concerned with how the interpretation of phenomena occurs. In the semiotic tradition, interpretation is considered to be separated from reality, but in phenomenology interpretation literally shapes what is real to that person. Most of the phenomenologists today hold to the idea that experience is subjective, not objective. They believe that subjectivity is a type of important knowledge in itself. The things of the world do not exist independently of the knowing; rather, people give meaning to things through personal contact with them. Thus, any 
phenomenological experience is necessarily a subjective experience. What is real is what is available for us, packed in language. (Craig: 2017: 138)

Phenomenology is a part of the communication research tradition. For phenomenology, communication is a collection of experiences of oneself and others in a dialogue. Phenomenology views communication problems, like semiotics, developing in gaps between various subjective viewpoints that a person cannot naturally directly experience other consciousness and the potential to understand intersubjective is limited. To solve this problem, there are two different approaches, namely semiotics and phenomenology.

The phenomenology in this study reveals the different and unique experiences of audiences about their viewing behavior in this millennial era or online media. They have different behaviors influenced by differences in interests, attitudes and orientations the value it holds. Different behavior is also due to environmental factors that requires if millennial era with powerful online media is able to create new decent behavior, on the other hand the old media behavior is still persists.

The study of phenomonology in communication science is called communicology, at the end of 1950s, in the United States, the phenomenological theory of communication was adopted with the name of communicology. Communicology is the study of various social phenomena as a result from the process of mass communication, group communication, and interpersonal communication. In 1967, Keith Brooks in his book The Communicative Arts and Science of Speech states that what is meant by communicology is integration of communication principles proposed by experts from various disciplines.

Communicology can also be interpreted as a realistic communication philosophy, a systematic research that examines a variety of communication theories, bridging gaps in knowledge, provides various interpretation and mutually validate the discovery in which communicology is a broad program that covers without limiting himself toward some various interest or various techniques of each academic discipline (Efendi, 1987 : 5-6). On the other hand, according to Richard L. Lanigan (2015: 1) communicology is the science of human communication as a communication medium (not a communication channel) for 4 (four) level experience of interconnected interaction, namely intrapersonal (embodied) interpersonal (dyadic), group (social), and inter-group (culture). The terminology of communicology has now evlved from its original form which emphasize interpersonal communication to various phenomenological level. (https://pakarkomunikasi.com/teori-fenomenologi)

Furthermore, to describe the behavior of the audience in this study is using individual difference theory. The theory of individual difference was introduced by Melvin D. Defleur with the name "Individual Defferences of Mass Communication Theory Effec"t. This theory examines differences in individuals as targets of mass media when they are exposed to it so it emerge a certain effect. (Rakhmat, 2007: 19) Individual difference theory states that individuals as members of the mass media suggestion audience are selective, paying attention on messages, especially if they are related to their importance, consistent with their attitudes, in accordance with the beliefs that are supported by his values. The response to the message was changed by its psychological structure, so the mass media effect on the mass audience is not same rather they are vary because individually they are different from one another in structure psychology. (Rakhmat, 2007: 19) Humans vary in the diversity of their psychological organizations, personally. Biological differences, different knowledge, different views, different environments build the attitudes, values and beliefs that constitute an order psychologically

Meanwhile, the effectiveness of commercial messages is described by the concept of advertisement viewability. In line with viewing behavior, viewability research consider it the 
most suitable and most measurable. The cocept of viewability is the extent to which advertisement in the media can be measured in terms of their visibility. Television advertisements have some sections which include visual color, images, sound, music, endorsers, and low and context messages. By paying attention on broadcast time, the type of program and how long it takes to advertise will affect this viewability.

\section{Methodology}

This research was conducted in Semarang Municipality as the capital city of Central Java with indicators high economic indicator. The data collection method and interpretive research are in-depth interview, participatory observation, observation, and interactive analysis. Researchers and informants work together, provide information to each other, exchange information, having dialogue and exchange meaning so that research results can be agreed upon. On the participate format, the relationship between the researcher and the researched is unifying and the relationship is holistic. Jorngensen (1986) suggests that the participatory observation method or observation involved must be defined based on 7 characteristics, they are as follows:

a) Special interest in human meaning and interaction based on insider perspectives or members of certain situations or circumstances.

b) The research foundations and methods are the presence and present day of everyday life.

c) Forms of theory and theory that emphasize the interpretation and understanding of human existence.

d) Logic and research processes that are open, flexible, opportunistic, and require redefinition of what is the problematic, based on facts obtained in real situations of human existence.

e) In-depth design and approach, qualitative and case studies.

f) Applying the role of participants which requires direct relationship in the field.

g) The use of direct observation with other methods of gathering information.

The strategy used quoted some steps from Seiddel (Sutopo, 2002, p: 33), they areas follows :

a) Take note sthat produce field notes, hereby code in order the data source remain traceable;

b) Collecting, sorting, classifying, synthesizing, making overview and create an index;

c) Thinking, by making the data category meaningful, seeking and finding patterns, and relationship; and

d) Make general findings

The analysis technique would be done using an interactive analysis model (Miles \& Huberman, in Sutopo, 2002, page: 186). In this analytical model, there are three components, namely data reduction, data presentation, and drawing conclusions or verification, the activities are carried out in an interactive form with the data collection process as a cyclical process. Data reduction was done by making a summary of the field notes. Researchers also make coding, focusing the theme, defining the boundaries of the problem, and also writing a memo.

Qualitative research tends to use selective sampling techniques with considerations based on the theoretical concepts used, the personal curiosity of the researcher, empirical characteristics, etc. Therefore it is "purposive sampling", or "criterion-based selection" (Goetz \& LaComte in Sutopo, 2002, p: 185). In this case, the researcher will select the informant who is considered to know the most, so that it is possible the choice of informants can develop according to the needs and stability of researchers in obtaining the data (Patton, in Sutopo, 
2002, p: 185). Snippets like this are more likely as "internal sampling" (Bogdan \& Biklen, in Sutopo, 2002, p: 185) which gives chance that a decision can be made once the researcher has a common mind that comes up about what is being studied, will readily speak, when it is necessary to do precise observation or time sampling, as well as the number of documents to be studied

To ensure and develop the validity of the data to be collected, this qualitative research used data validity techniques, namely triangulation techniques. From four kinds of triangulation techniques, namely data triangulation, researcher triangulation, triangulation methodological, and theoretical triangulation, (Patton, in Sutopo, 2002, p: 186), it would be using triangulation of data or triangulation of sources.

\section{Result and Discussion}

Television viewing behavior is described in several categories according to young audience activity when they are consuming television. The behavior of rarely watching television is one of the behaviors of young people. When it started to rarely watch television, television is considered as a media that is not mobile, impractical, less attractive. Those are the main and a logical reason for an active young people carry out various activities at home and outside the home. Joining with friends, going on a chat and using a smartphone that is more practical and economical. The use of certain smartphones also make young people become more confident, because they create an modern, smart and cool impression. As Malvin D. Defleur stated that environmental factors like the emergence of new media or online media are able to influence individual behavior in their relation to the mass media.

Second, the skip behavior appears by pressing the move button when the advertisement is airing. Young people are still watching television but they skip or switch the channels to another one. One of the reasons is because advertisements are no longer interesting to watch. Another reason is they watch television but they do not focus on it. It is not the era anymore when young people watch an advertisement sitting in front of the media because it will be boring for them so they watch the advertisement casually or by doing various activities such as eating, chatting, playing gadgets and so on. Denies Mc Quail said that one of the reason function of the mass media is to entertain. The mass media is watched for entertaining and escaping from boredom.

Next, the emergence of viewing behavior but neglecting it, some young people still watch television advertisement in this online media era, but they do not enjoy wholeheartedly. They tend to be unfocused and ignore the advertisement. If they were asked about what the media has recently aired, they don't know. It means that they watch but do not enjoy it. So advertisement really do work for entertainment only.

Watching television advertisement and skipping the advertisement airing has appeared several times. It means advertisements repeated in a high frequency. The exact reason is tedious. The individual difference theory indeed can answer that the mass media message will be received in different ways by each individual. Because of the belief in media content will get different feedback. Almost the same with the skip behavior, young people watch television advertisement if they are interesting. The young people general has aspecific reason to interact with the media, even more they enjoy commercial advertising messages. One of the reason is to avoid boredom and getting out of the tiring daily routine. High advertising creativity is required to be able to display attractive advertisements so that the advertisement continues to be watched. Advertising strategy applied by the advertising industry needs to be sharpened to 
displays creative and attractive advertisement. Among them were showing events with idol endorsers, display favorite products such as food and beverage or fashion. The attractive advertisement has many features such as evocative advertisement jungles, wacky messages, storylines which makes audiences curious, etc.

Another behavior is watching advertisements if the advertisement is motivating, according to the audience, there is advertising messages is very motivating in providing life solutions. Young people wants a show with dynamic, engaging activities, can give enlightenment and generate new thoughts. This advertising message appears in the form of fresh ideas for young people such as natural outdoor advertising, and so on. Media is a window to the world, the world of reality is really narrow, and how audiences can be motivated by the free world he had never been there. Completed with almost the same behavior is watching an advertisement if it is creative, different, new, extraordinary, it is the advertisement that the young audience has been waiting for. The appearance of the advertisement is different. Hair does not have to be black, clothes do not have to be formal, house does not have to be big, car does not have to be luxury, the motorbike does not have to be full of accessories, and gadget does not have to be smart. Creativity can create something else. Watching creative advertisements makes the audience enjoy the advertisement. There are viewers who enjoy the commercials carefully, until they memorize the advertisement jingle lyrics. Even they memorize the song, jingles, endorsers and unique phrases which later they kept in mind for a long time.

Another viewing behavior is watching if the advertisement is a beauty product, advertisements for beauty products such as make-up equipment can arouse the audiences' feelings of liking to continue enjoying it. Beauty product advertisements always show beautiful endorser with perfectly bodied, long hair and leggy. A scene like this makes the audience exciting to see the beautiful display. Especially for women, smooth skin, a white and clean face is a dream. So display of the advertisement with the support of high lighting art technology is able to create dazzling advertising stars and riveting. Woman is a symbol of beauty. The world is jewelry, but the most beautiful jewelry is a good woman. (HR: Bukhori Muslim)

The audience watches advertisement if they want the product offered, or if there is new product information. Advertising has a role as informative media content and meeting the interests of the public in obtaining various kinds of information. Advertisement has a persuasive function. Sometimes the function of persuasion appear most dominant in advertisement airing. Through creativity and advertising strategies, advertising designed to be able to persuade the audience so that the audience is interested in buy. According to Everett $\mathrm{M}$ Rogers, if you want an innovation spreading in society then use the mass media. (Rogers, 1961)

The next behavior is watching advertisements because they know that there is a new product, advertisements has an informative function (Dennis Mc Quail, 2010) Advertisement provides new knowledge for the audience especially the information of a new product. Advertisement helps a young people find the product they are looking for or a product that will create desire for young people. Products that young people like the most nowadays are related to fashion namely clothing, body care and accessories. This includes gadgets, motorbikes and cars.

Watching advertisements because it is inspiring, creative advertisement are inspiring young people. Advertising motivates the emergence of new, different and dynamic ideas. The last is watching television behavior if it is accidentally advertisement message appears on broadcast in selected media content. Because they have content expected which is healthy to watch. There are families of young people who are deliberately limiting watching television 
because they do not want their children to b'e addicted to the information they think they are not good. In this family, the children are directed to focus on studying because they have special program.

\subsection{Viewability}

Viewability in this study includes colors, written messages, voice messages, music, and endorsers. The duration of advertisement on television for 15 seconds to 1 minute creates a glimpse message viewability. No wonder that the short duration makes the advertisement has to be repeated. Despite the method create audience boredom. Young people are unable to follow the advertising messages which is fast if the audience has no interest at all with the advertising message on the television advertisement. But the reality is different, first, the audience watches the interesting advertisement. The appeal of the advertisement is able to create an amaze atmosphere so that the audience does not move away from the advertisement. It also includes inspiring, creative, and attractive advertisements. It is also motivated by the need to find a product that becomes his needs and wants.

It is then young people are able to name the dominant color of the advertisement, imitating the message of the advertisement sound, imitating advertisement music jingles and song lyric, imitating advertising style of speech and understand the intent of the advertising message. Even in high context, the audience is able to understand the meaning implied from the advertising message. In viewability, advertisements is still exist to be watched in this specific group.

\subsection{Islamic Value}

Islam teaches in the word of Allah "And I did not create jinn and humans except to worship me "Adz Dzaariyat: 56. Humans live in the world only to worship, both worship which is obligatory under God's command or worship that is cumpolsory with the guidance of the Prophet. Humans should do something in this world because of the mere desire to worship, so doing something sincerely and only hope for the pleasure of Allah. Because of this motivation, humans do something, and they do not just a waste of time. Humans have a strong motivation in doing activities because it meets important needs. Moreover, Human also leave something missing or not useful. Leaving something that is permissible even though it is not sinful but also not merit. This verse strengthens the behavior of young people when they have to leave or ignore anything that is less useful. Entertainment is important but in priority entertainment is not urgent so it can be done at a another time. Another problem if you have important needs such as seeking information or fulfilling needs.

When humans find an important need, they should mean it or being serious in doing it. $\mathrm{Al}$ Mukminun: 2, "(Namely) those who are serious in prayer ", becomes the basis for humans to be absorbed in doing the mandate or responsibility. Being solemn means concentration, calm, earnest and full humility so as to consciously feeling what is being done and be able to understand when they are studying. Likewise when people are looking for information. Sincere people will be able to receive, digest and understand information received through the mass media. 


\section{Discussion}

In the middle of the domination of online media, is television still the first choice for broadcasting commercial messages such as advertising? In the midst of the death of national television and the arrival of the world economy which removes the boundaries of cultural diversity, both opportunities and challenges arise with Indonesia's new policy of digital television, can digital television fulfill its high expectation from the public to deliver the regional voice? (Ahmad Toni, 2016: 36) When television was booming in Indonesia in the 1960s, the media estimated that this was the time the era of the death radio media. Decades passed but radio is still exists on the air with young people as the separate listeners. Create a unique community and segment specifically for radio listeners.

The emergence of online media as a converging media which is able to serve the needs of various types of media, namely, print, audio and audio-visual media, are a problem. Online media has high technology that can penetrate the global region and almost perfect service completeness which can collaborate with old media television. Converging online media tools are optimized for the use of interests of several existing media. So the society will not experience problems such as limited device functionality. Problems arise socially. Advertisements need to determine the target audience for television audiences, determine the target life journeys accurately so that the advertisement on television has a specific audience. Creating a new theory that is able to reveal the phenomenon of media transition. There is no need to turn off the theory. Is not a theory which is ever existed and created already able to answer phenomena, technology and societal problems in its era. The advertising industry is creative advertising continues to be challenged to create a unique, specific creative advertisement that the work will still be enjoyed by the public.

\section{References}

[1] Al Quranul Karim, translated version.

[2] Ahmad Toni, Pasca Matinya Televisi Nasional dalam Perspektif Jurnalistik, Vol.8 N0.1 2016, page : 36-50 Deddy Mulyana, 2006,

[3] Metodologi Penelitian Kulaitatif, Paradigm Baru Ilmu Komunikasi dan Ilmu Sosial Lainnya, Bandung, Remaja Rosdakarya.

[4] Jalaluddin Rachmat, 2007 Psikologi Komunikasi, Bandung, PT Remaja Rosdakarya.

[5] Engkus Kuswarno, 2007, Tradisi Fenomelogi pada Penelitian Komunikasi Kualitatif : Sebuah Pedoman Penelitian dan Pengalaman Penelitian (Engkus Kuswarno), Jurnal Sosiohumaniora, Vol 9 N0 2 Juli 2007, 161-176.

[6] Stephen W Littlejohn, 2017, Theories of Human Communication eleventh edition,USA, Waveland Press Inc,

[7] Sutopo HB, 200, Metodologi Penelitian Kualitatif, Dasar Teori dan Terapannya, Surakarta, Universitas Sebelas Maret Press.

[8] Robert T. Craig, 1999, Communication Theory as a Field, nine edition, 138

[9] Magnaglobal.com downloaded on 20 Agustus 2020

[10] https://id.wikipedia.org/wiki/Kajian_media, downloaded on 27 Desember 2019

[11] https://www.nielsen.com/id/id/press-releases/2020/belanja-iklan-2019-ditutup-dengantrenpositif/, downloaded on 18 agustus 2020

[12] https://www.researchgate.net/publication/317947993_New_era_of_TVwatching_behav ior_Binge_watching_and_its_psychological_effects downloaded on 20 Agustus 2020 
[13] https://gadgetren.com/2020/01/25/daftar-paket-axis-di-tahun-2020-96566/ downloaded on 20 Agustus 2020 